\title{
A COMMUNITY OF FLOWER-VISITING BEES (HYMENOPTERA: APOIDEA) IN THE COASTAL SAND DUNES OF NORTHEASTERN BRAZIL
}

\author{
${ }^{1}$ Blandina Felipe Viana \& ${ }^{2}$ Astrid de Matos Peixoto Kleinert
}

Biota Neotropica v5 (n2) - http://www.biotaneotropica.org.br/v5n2/pt/abstract?article+BN00305022005

\author{
Date Received 08/15/2004 \\ Revised 05/22/2005 \\ Accepted 07/01/2005
}

\begin{abstract}
${ }^{1}$ Departamento de Zoologia, Instituto de Biologia, Universidade Federal da Bahia, rua Barão de Geremoabo s/n, Campus Universitário de Ondina 40170-110, Salvador, Bahia, Brasil. Home page: http://www.labea.ufba.br, e-mail: blandefv@ufba.br

${ }^{2}$ Departameno de Ecologia, Instituto de Biologia da Universidade de São Paulo, Rua do Matão, Trav. 14, n 321, CEP 05508-900, São Paulo, SP, Brasil. astridkl@ib.usp.br
\end{abstract}

\begin{abstract}
We analyzed aspects of the community structure of Apoidea of a restricted area of dunes with restinga vegetation in Salvador, Bahia, Brazil. Standardized samples were taken for one year, 3 times a month from 6:00 a.m. to 6:00 p.m. A total of 3983 individuals (3770 females and 213 males) of 49 species, grouped into 13 morpho-functional types and belonging to five families, were collected from flowers in its majority. The fauna of Abaeté is composed by large solitary bees, best represented by Anthophoridae followed by Apidae; Halictidae; Megachilidae and Colletidae. Bees were active throughout the year, with peaks of abundance in periods of low rainfall. Daily activity was greatest between 08:00 and 14:00 hours, when relative humidity was lower and temperature higher. The abundance pattern and the richness were very similar to other habitats in the Brazilian Northeast. Of the species sampled, 49\% were represented by less than eight individuals. The six most abundant species were represented by $84 \%$ of the total individuals collected. The availability of resources seems to be the main factor regulating bee flight activity in Abaeté. The foraging activity was related positively to the intensity of flowers in the field.
\end{abstract}

Key words: bee's abundance; bee diversity; community structure, restinga and dunes, morpho-functional groups, Northeast Brazil.

\section{Resumo}

Aspectos da estrutura da comunidade de Apoidea de uma área restrita de dunas com vegetação de restinga em Salvador, Bahia, Brasil, foram analisados. Amostragens, com metodologia padronizada, foram realizadas durante 1 ano, 3 vezes por mês, das 6:00h às 18:00h. Um total de 3983 indivíduos (3770 fêmeas e 213 machos) de 49 espécies, agrupadas em 13 categorias morfo-funcionais, pertencentes a 5 famílias, foram coletados nas flores. Em sua maioria, a fauna de Abaeté é composta por abelhas solitárias de porte grande, cuja maior representatividade, tanto em espécies quanto em indivíduos, é de Anthophoridae, seguida por Apidae; Halictidae; Megachilidae e Colletidae. As abelhas estiveram ativas durante todo o ano, apresentando picos de abundância no período de menor precipitação pluviométrica. A atividade diária foi maior entre 8:00h e 14:00h, compreendendo o período em que a umidade relativa decrescia e a temperatura aumentava. O padrão de abundância e a riqueza foram bastante semelhantes ao de outros habitats no nordeste brasileiro. 49\% das espécies amostradas foram representadas por menos de 8 indivíduos e apenas 6 espécies predominaram, representando 84\% do total de indivíduos coletados. A disponibilidade de recursos parece ser o principal fator regulador da atividade de vôo das abelhas em Abaeté, ao longo do ano. A atividade de forrageamento foi relacionada positivamente com a intensidade de flores no campo.

Palavras-chave: abundância, diversidade, estrutura de comunidades, restinga e dunas, grupos morfo-funcionais, Nordeste brasileiro. 


\section{Introduction}

Until the mid sixties, all that was known of the Brazilian melissofauna depended on the works done at the beginning of the century by Ducke (e.g. 1902; 1906; 1908; 1910), in Amazonas, Pará, Maranhão and Ceará. This only changed when Sakagami et al. (1967) began collecting data with a biocenotic focus, using a standardized methodology. Since then more than 50 investigations on Apoidea communities have been carried out in Brazil, providing valuable information about the local diversity, relative abundance, preferential habitats and changes in the frequency of bee flower visitors, in the investigated areas.

However, most $(>80 \%$ ) of these studies are restricted to the ecosystems of cerrado and forest regions in the south and southeast of the country (Pinheiro-Machado et al. 2002). The bee fauna of the coastal ecosystems, however, remained practically unknown. Considering its vast geographical size, the works done on these ecosystems are still both scarce and localized (Gottsberger et al. 1988, Albuquerque 1998, Alves dos Santos 1999, Silva \& Martins 1999). This paucity hinders a broader analysis of regional patterns.

Due to their location, these coastal ecosystems are under accelerated fragmentation process caused by anthropogenic activity. The environment of the dunes in particular presents greatest fragility, because if the dunes are destroyed or reduced as a result of a reduction in the vegetative cover and removal of sand, the ecosystem can never be restored.

The work carried out on the plant-pollinator relationship among the dunes of Maranhão by Gottsberger et al. (1988) emphasizes the importance of bees as pollen vectors in such an environment. According to those authors, of ten plant species present in the dunes, nine were melittophilous, and 18 bee species functioned as flower visitors and pollinators.

The Environmental Protection Area of the Lakes and Dunes of Abaeté constitutes one of the more notable sites in the belt of dunes that extends along the Atlantic coast of Bahia towards the north and into Sergipe. It represents an area of great biological relevance, given its high species diversity. It is an exception to the usual sand dune areas due to its high degree of plant endemism, since sand dunes, as a rule, present few endemism (Araújo \& Lacerda, 1987).

This study was focused on a particular area of this ecosystem, with the objective of augmenting knowledge on the melissofauna of the Brazilian sand dune ecosystems, seeking answers to the following questions: 1) Do the Abaeté dunes have a bee fauna characteristic of and convergent with the fauna of similar ecosystems? 2) What is the structure of that fauna, concerning its composition and abundance? 3) Is there a daily, seasonal and annual pattern in the flight activity of bees in the dunes of Abaeté?

\section{Material and methods}

\section{a) Study Area:}

Samples were taken in an area of 8.2 hectares of dunes located in the Area of Environmental Protection of the Lakes and Dunes (Área de Proteção Ambiental de Lagos e Dunas) of Abaeté, Salvador, Bahia, Brazil, at $38^{\circ} 21^{\prime} \mathrm{W}$ and $12^{\circ} 56^{\prime}$ S.

According to the Köppen classification, the local climate is Af: hot and humid, without a dry season. The greatest concentration of rainfall occurs from March through August. The annual mean temperature is $25.3^{\circ} \mathrm{C}$ and the annual precipitation is $2100 \mathrm{~mm}$. During most of the year, the relative humidity remains above $70 \%$ and, in some months, it is over $80 \%$.

The vegetation covering the dunes of Abaeté represents a distinct type of sand dune vegetation, and was classified by Eiten (1968) as "Evergreen broadleaf open clumped scrub”, i.e. a type of perennial bushy vegetation with broad leaves forming thickets, whose structural likeness is closest to those of the Amazonian flatlands (Morawetz 1983). It is characteristically distributed and well delimited by thickets that consist of one or more plant species, usually not over three meters in height, thus forming ecological islands (Ribas et al. 1994).

\section{b) Samplings of the Bees:}

Samplings were undertaken by two persons over a 12-month period (January to December 1996), three times a month, at intervals of approximately 10 days, except for April, during which rains impeded collection. The duration of each sampling was 12 hours, from 6:00 a.m. to 6:00 p.m., totaling 840 hours (420 hours per collector).

The methodology for sampling the bees on the flowers was that of sweeping with an entomological net, based on the procedure described by Sakagami et al. (1967). In the event that no bee was observed as the collector approached the plant, the sweeping proceeded anyway. The maximum time of collection at each plant in bloom was 10 minutes.

The individual bees collected were killed in ethyl acetate and placed in glass flasks labeled with the following information: place, date, time of day, plant species and resource. Later, in the laboratory, these data were transferred to the label of each specimen.

The meteorological data for each day of collection and the total monthly values were obtained from the meteorological station at the Deputado Luis Eduardo Magalhaes Airport, Salvador, Bahia.

\section{c) Identification of the morpho-functional categories:}

The collected bees were measured in terms of body size with the aid of a caliper, and length of glossa using a millimetric ruler. 
The body size of each bee, was considered to be the total length of the body and the width of the thorax, and was classified into five divisions:

-Large mass: total body length $>14.0 \mathrm{~mm}$. Thorax width $>6.0 \mathrm{~mm}$.

-Medium robust mass: total body length 10.0 to 14.0 $\mathrm{mm}$. Thorax width 4.0 to $6.0 \mathrm{~mm}$.

-Medium thin mass: total body length 10.0 to 14.0 $\mathrm{mm}$. Thorax width 3.0 to $4.0 \mathrm{~mm}$.

-Medium to small mass: total body length 7.0 to 10.0 $\mathrm{mm}$. Thorax width 2.0 to $3.0 \mathrm{~mm}$.

-Small mass: total body length no more than $7.0 \mathrm{~mm}$. Thorax width $<2.0 \mathrm{~mm}$.

In regard to the length of glossa, five categories were also considered:
-Very long: > 12.0 mm
-Long: 7.0 to $12.0 \mathrm{~mm}$
-Intermediate: 3.0 to $6.9 \mathrm{~mm}$
-Short: $<3.0 \mathrm{~mm}$

-Short bilobate: $<3.0 \mathrm{~mm}$

These classifications were based on standards defined by Roubik (1989) and Michener (2000).

The specimens were grouped into morpho-functional categories, according to the following characteristics: a) method of obtaining resource; b) specialties as: adaptations for perforating the corolla and for oil-collection; c) method of pollen uptake; d) method the pollen was being transported; e) body pilosity; f) length of glossa; and g) body length and thorax width.

\section{d) Data Analysis:}

The indexes by Shannon-Wiener (H’): H’= -Ó pi. $\log _{10}$ pi, where pi is the proportion of i species in the samples, and Pielou (J'): J'= H'/H'max, where H'max is the logarithm of the total number of species in the samples (Ludwig \& Reynolds 1988) were applied for calculating the diversity of species and the evenness, respectively.

The data set was organized by sampling effort in chronological sequence thus obtaining the species accumulation curve.

The representation of the frequency distribution of the species classified according to the number of individuals was done by applying Preston's methodology (1948 apud Southwood \& Henderson 2000), adjusted to the truncated lognormal (Ludwig \& Reynolds op. cit.).

Faunistic similarity was analyzed using Morisita's index (Krebs 1998), which considers the abundance values of each species. The calculations are based on: $\mathrm{C}_{1}=2 \mathrm{Sn}_{1} \mathrm{n}_{2} /$ $\left(l_{1}+l_{2}\right) N_{1} N_{2}$, where $n_{1}$ and $n_{2}$ are respectively the numbers of individuals of the same species in the samples; $l_{1}$ and $l_{2}$ are the values of 1 of two samples, where $l i=S n(n-1) / N(N-1)$ and $\mathrm{N}_{1}$ and $\mathrm{N}_{2}$ are the number of individuals of all of the species in the two samples. This index varies from 0 (not similar) to 1 (completely similar).

For the calculation of the predominant species of Apoidea and the confidence limits, the Kato et al. method of probability was used (1952 apud Laroca 1995). This technique consists of converting the frequencies into percentages. In addition, the upper and lower confidence limits were calculated by means of the probability of occurrence method. In accordance with this analytic technique, species were considered predominant when the lower confidence limit was greater than the inverse of the number of species multiplied by 100, or in other words, the percentage to be expected in the event when there is no dominance.

To verify whether there was a significant annual variation in the meteorological data, and in the relative abundance of the individuals of Apoidea the $c^{2}$ test was applied.

Most of the analyses were done using SPSS for Windows and the SAS System.

\section{Results}

In all, 3983 individuals were collected and these were distributed among 49 species (including the morpho-species), belonging to 23 genera of five families of Apoidea: Colletidae, Halictidae, Megachilidae, Anthophoridae and Apidae (sensu Michener 1965). The species of Apoidea were grouped into 13 morph-functional categories (Table I). In most cases, categories agreed with taxonomy at the genus level (Table II).

Anthophoridae was the family best represented in terms of number of species, morpho-functional categories and individuals (26 spp, 5 mfc, 2373 individuals), followed in decreasing order by Apidae (10 spp, 3 mfc, 1321 individuals), Halictidae (6 spp, 2 cmf, 159 individuals), Megachilidae (5 spp, $1 \mathrm{mfc}, 105$ individuals) and Colletidae (2 spp, $2 \mathrm{mfc}$, 25 individuals) (Table II).

Regarding the number of species by morpho-functional category, only two categories presented a number larger than five species, CENTRIDINI (14 spp) and XYLOCOPA (6 spp). The other categories were represented by five or less species (Table II).

Six species predominated in the sampling: Pseudoaugochloropsis pandora (Smith, 1853), Centris (Centris) caxiensis Ducke, 1907, Centris (Centris) leprieuri Spinola, 1841, Xylocopa (Neoxylocopa) cearensis Ducke, 1910, Apis mellifera Linnaeus, 1958 and Trigona spinipes (Fabricius, 1793). Together, these species accounted for $84 \%$ of the individual specimens and corresponded to five morphfunctional categories (Table II).

The frequencies distributions of the species in relation to their classes of abundance conform to log-normality (Figure 1). 


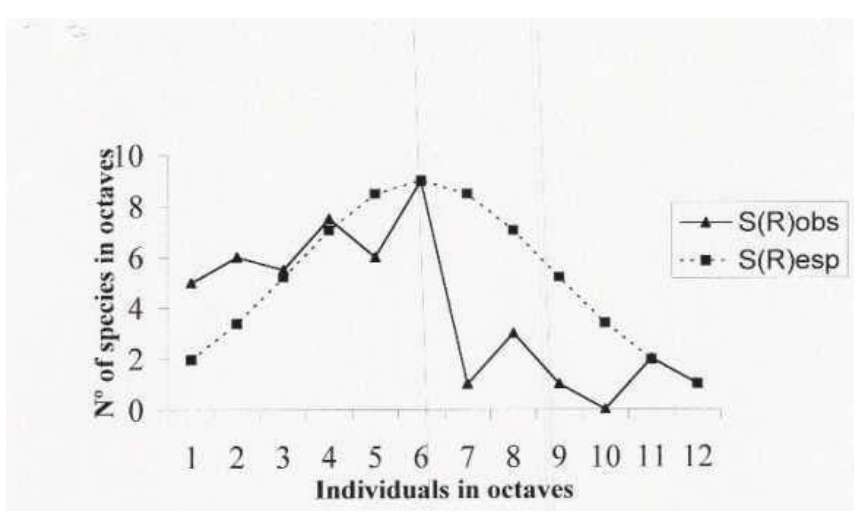

Figure 1. Distribution of the frequencies of bee species in classes os octaves (equal log2), observed curve (ef. Preston, 1948), and adjusted to lognormal (expected) (cf. Ludwig \& Reynolds, 1988), in Abaeté, Salvador, Bahia State.

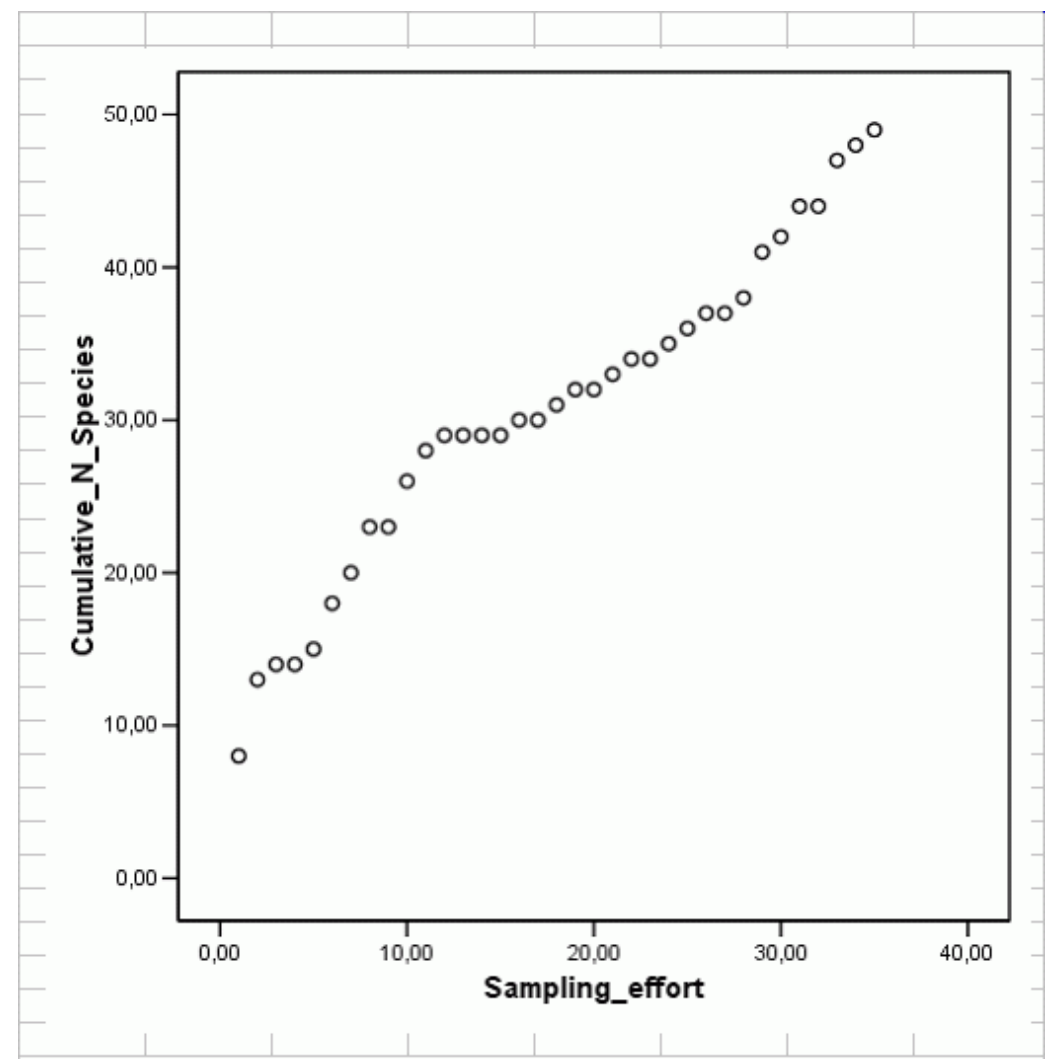

Figure 2. Species-accumulation curve for the bee fauna of Abaeté, Salvador, Bahia from January to December 1996

http://www.biotaneotropica.org.br 

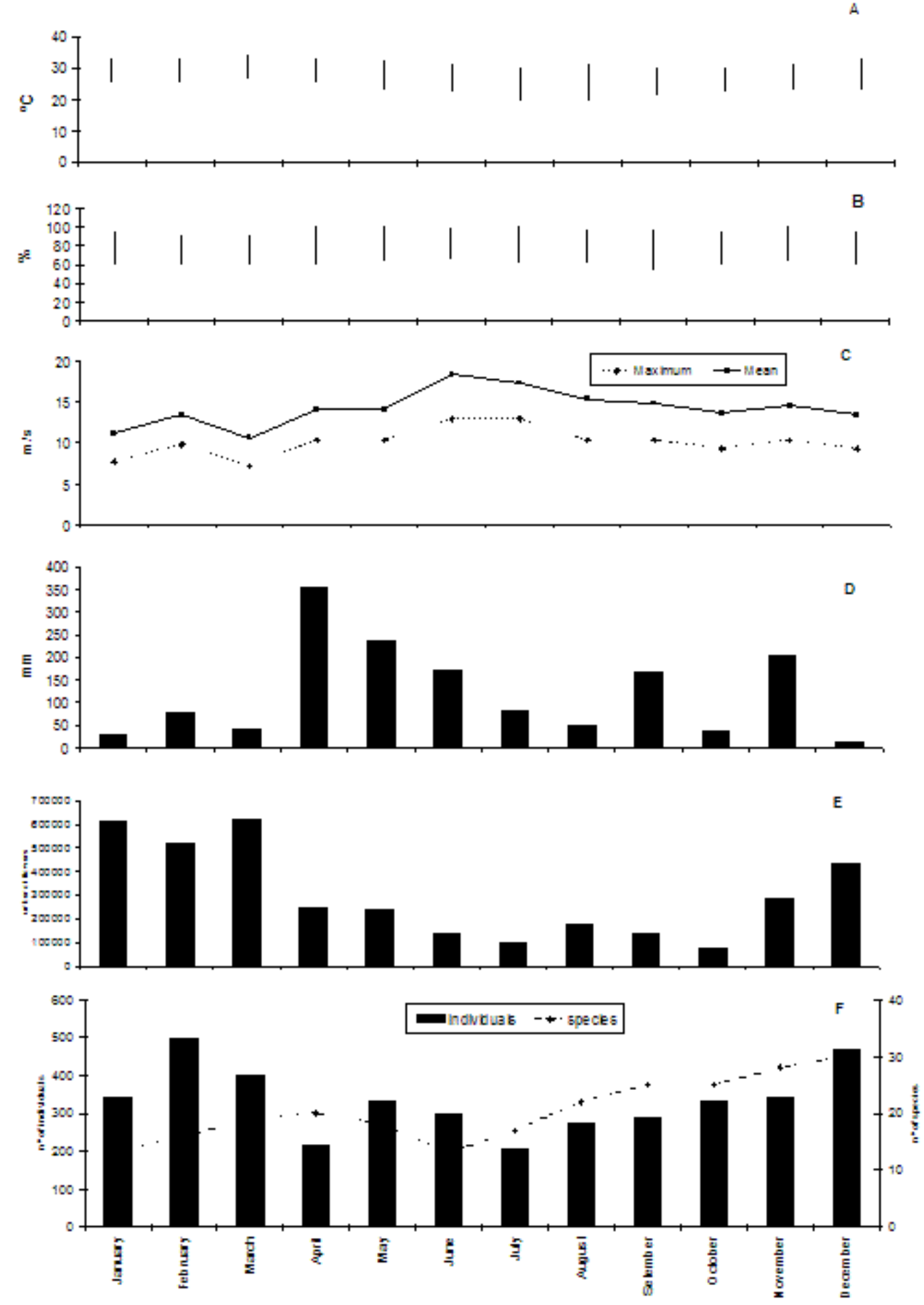

Figure 3. Relationship between biotic and abiotic factors and the number of individuals of Apoidea collected from January to December 1996, in Abaeté, Salvador, Bahia. (A=Temperature; $B=$ Relative humidity; $C=$ Wind speed; D=Rainfall; $E=$ Flowering intensity; F=Number of individuals and of species of Apoidea).

http://www.biotaneotropica.org.br 
Figure 4. Daily activity of Apoidea individuals collected from flowers, in Abaeté, Salvador, Bahia State, from January to december 1996.

\begin{tabular}{|c|c|c|c|c|c|c|c|c|c|c|c|c|c|c|c|c|c|c|c|c|c|c|c|c|}
\hline \multirow[b]{2}{*}{$\begin{array}{l}\text { MOEFHO } \\
\text { FUNCTONAL } \\
\text { CATEGORIES }\end{array}$} & \multirow[b]{2}{*}{$\infty$} & \multicolumn{2}{|c|}{$\begin{array}{l}\text { Menns of obtaining } \\
\text { resuroe }\end{array}$} & \multirow[t]{2}{*}{ Specialities } & \multicolumn{4}{|c|}{ Meres of pollen wotke } & \multicolumn{4}{|c|}{ Bkans of pollen trangortiticn } & \multicolumn{2}{|c|}{ Body hair } & \multicolumn{5}{|c|}{ Body size } & \multicolumn{5}{|c|}{ Length of glosss } \\
\hline & & howe & Nerpacis: & & $\begin{array}{l}\text { Fue } \\
\text { lag }\end{array}$ & $\begin{array}{l}\text { Fand } \\
\text { mone }\end{array}$ & Nembitias & Thative & Catienc: & 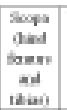 & $\begin{array}{l}\text { Tanas } \\
\text { Socops }\end{array}$ & 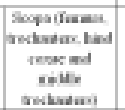 & Drews & Sman & $w$ & $\begin{array}{l}\text { Mobs: } \\
\text { neted }\end{array}$ & $\underset{\text { Shase: }}{\text { the }}$ & $\mid \begin{array}{c}\text { Sichessos } \\
\text { adil }\end{array}$ & $\operatorname{sen} \mid$ & \begin{tabular}{|l|} 
Nang \\
key
\end{tabular} & Less & Lucuedac & stave & $\begin{array}{c}\text { Sast } \\
\text { Mkt=s }\end{array}$ \\
\hline $\begin{array}{c}\text { Mesopls and } \\
\text { Mesconithium litcriam }\end{array}$ & $\begin{array}{c}\operatorname{sen} \\
1\end{array}$ & $\mathrm{~s}$ & & & & & & & & & & & & $\mathrm{x}$ & & $\mathbf{x}$ & & & & & & $\mathrm{x}$ & & \\
\hline $\begin{array}{c}\text { Euglossieve and Bombus } \\
\text { meio }\end{array}$ & FEAn & & $x$ & & & & & $\mathrm{x}$ & $x$ & & & & $\mathrm{~s}$ & $\mathrm{~s}$ & $\mathrm{~s}$ & $x$ & & & & $\mathrm{~s}$ & $\mathbf{s}$ & & & \\
\hline Trigied يpinizis & Ts & & $x$ & 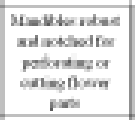 & $\mathrm{s}$ & & & & $\mathrm{x}$ & & & & & $\mathrm{s}$ & & & & & $s$ & & & & $\mathrm{x}$ & \\
\hline $\begin{array}{l}\text { OutworTrganim and Apes } \\
\text { mellifen }\end{array}$ & TAm & & $x$ & & $\mathrm{~s}$ & & & & $\mathrm{x}$ & & & & & $\mathrm{x}$ & & & $x$ & & $\mathrm{~s}$ & & & $\mathrm{x}$ & $x$ & \\
\hline Xylocopo & Xy & & $x$ & 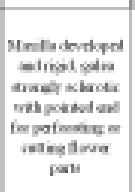 & & & & $\mathrm{x}$ & & $\mathrm{x}$ & & & $\mathrm{s}$ & & $\mathrm{x}$ & & & & & & $\mathrm{s}$ & $\mathrm{x}$ & & \\
\hline Cenvieula & $\mathrm{cr}$ & & $x$ & & $s$ & & & & & $\mathrm{x}$ & & & & $\mathrm{s}$ & & & & & $\mathrm{s}$ & & & & $x$ & \\
\hline Flonlogas & $\mathrm{F}_{2}$ & & $\mathrm{x}$ & & & & $s$ & & & $\mathrm{x}$ & & & $\mathrm{s}$ & & & $x$ & & & & & & 8 & & \\
\hline Augostlesire & As & & $\mathbf{x}$ & & & & & $x$ & & & & & & $s$ & & & & $x$ & & & & & $\mathrm{x}$ & \\
\hline Dolictus & Di & & $\mathbf{x}$ & & $x$ & & & & & & & & & $x$ & & & & & $s$ & & & & $\mathbf{x}$ & \\
\hline $\begin{array}{l}\text { Disranthidum' } \\
\text { Pseubloventerum }\end{array}$ & DP & & $x$ & & $\mathrm{x}$ & $x$ & & & & & $\mathrm{x}$ & & & $\mathrm{x}$ & & $x$ & & $\mathrm{x}$ & & & & $\mathrm{x}$ & $\mathrm{x}$ & \\
\hline Colleses & $\mathrm{cl}$ & & $x$ & & $s$ & & & & & & & $s$ & $s$ & & & & & $x$ & & & & & & $s$ \\
\hline Chlsols & $\mathrm{Ch}$ & & $x$ & & $\mathrm{~s}$ & & & & & & & $x$ & & $x$ & & & & & $s$ & & & & & $\mathrm{x}$ \\
\hline Ceatndin: & o & & $\mathbf{x}$ & Mapidine & & & & $s$ & & $\mathrm{x}$ & & & $\mathrm{s}$ & & & $x$ & & & & $s$ & $x$ & & & \\
\hline
\end{tabular}

Table I - Characteristics used in the classification of the morpho-functional categories of Apoidea, collected in the Abaeté dunes, Salvador, Bahia State.

http://www.biotaneotropica.org.br 
Viana, B.F. \& Kleinert, A.M.P. - Biota Neotropica, v5 (n2) - BN00305022005

\begin{tabular}{|c|c|c|c|c|c|}
\hline Family & Morpho-functional category & Species & Female & Male & Total \\
\hline \multirow[t]{2}{*}{ COLLETIDAE } & Chilicola & Chilicola (Stenocelis) sp 1 & 2 & 0 & 2 \\
\hline & Colletes & Colletes petropolitanus Delatorre, 1896 & 23 & 0 & 23 \\
\hline Subtotal & & & 25 & $\mathbf{0}$ & 25 \\
\hline \multirow[t]{6}{*}{ HALICTIDAE } & Augochlorinini & Augochlora sp 1 & 1 & 1 & 2 \\
\hline & & Augochlora sp 2 & 27 & 2 & 29 \\
\hline & & Augochloropsis callichroa (Cockerell, 1900) & 10 & 4 & 14 \\
\hline & & Augochloropsis sp 1 & 1 & 0 & 1 \\
\hline & & Pseudaugochloropsis pandora (Smith, 1853) & 61 & 43 & 104 \\
\hline & Dialictus & Dialictus (Chloralictus) opacus Moure,1940 & 6 & 3 & 9 \\
\hline Subtotal & & & 106 & 53 & 159 \\
\hline \multirow[t]{5}{*}{ MEGACHILIDAE } & Dicranthidium/Pseudocentrum & Dicranthidium arenarium Ducke, 1907 & 0 & 1 & 1 \\
\hline & & Dicranthidium luciae Urban, 1992 & 45 & 37 & 82 \\
\hline & & Pseudocentrum (Pseudocentrum) sp 1 & 7 & 0 & 7 \\
\hline & & Pseudocentrum (Pseudocentrum) sp 2 & 6 & 8 & 14 \\
\hline & & Pseudocentrum (Pseudocentrum) sp 3 & 1 & 0 & 1 \\
\hline Subtotal & & & 59 & 46 & 105 \\
\hline \multirow[t]{26}{*}{ ANTHOPHORIDAE } & Centridini & Centris (Centris) aenea Lepeletier, 1841 & 10 & 0 & 10 \\
\hline & & Centris (Centris) caxiensis Ducke, 1907 & 71 & 26 & 97 \\
\hline & & Centris (Centris) flavifrons Fabricius, 1775 & 19 & 0 & 19 \\
\hline & & Centris (Centris) leprieuri Spinola, 1841 & 191 & 21 & 212 \\
\hline & & Centris (Centris) nitens Lepeletier, 1841 & 3 & 1 & 4 \\
\hline & & Centris (Centris) spilopoda Moure, 1969 & 3 & 0 & 3 \\
\hline & & Centris (Hemisiella) tarsata Smith, 1874 & 7 & 0 & 7 \\
\hline & & Centris (Hemisiella) trigonoides Lepeletier, 1841 & 22 & 0 & 22 \\
\hline & & Centris (Paremisia) fuscata Lepeletier, 1841 & 4 & 0 & 4 \\
\hline & & Centris (Paremisia) pulchra Freitas et al 2003 & 24 & 7 & 31 \\
\hline & & Centris (Ptilopus ) sponsa Smith, 1854 & 1 & 0 & 1 \\
\hline & & Centris (Xanthemisia) lutea Friese, 1899 & 2 & 4 & 6 \\
\hline & Ceratinula & Ceratinula sp 1 & 1 & 10 & 11 \\
\hline & & Ceratinula sp 2 & 25 & 0 & 25 \\
\hline & & Epicharis (Xanthepicharis) bicolor Smith, 1854 & 0 & 7 & 7 \\
\hline & & Epicharis (Xanthepicharis) nigrita Friese, 1900 & 28 & 1 & 29 \\
\hline & Florilegus & Florilegus similis Urban, 1970 & 1 & 0 & 1 \\
\hline & Mesonychium/Mesoplia & Mesonychium littoreum Moure, 1944 & 0 & 4 & 4 \\
\hline & & Mesoplia sp 1 & 1 & 4 & 5 \\
\hline & & Mesoplia sp 2 & 0 & 1 & 1 \\
\hline & Xylocopa & Xylocopa (Megaxylocopa) frontalis Olivier, 1789 & 26 & 0 & 26 \\
\hline & & Xylocopa (Neoxylocopa) cearensis Ducke, 1910 & 1732 & 28 & 1760 \\
\hline & & Xylocopa (Neoxylocopa) grisescens Lepeletier, 1841 & 3 & 0 & 3 \\
\hline & & Xylocopa (Neoxylocopa) nigrocincta Smith, 1854 & 28 & 0 & 28 \\
\hline & & Xylocopa (Schoenherria) prov. subcyanea Pérez, 1901 & 38 & 0 & 38 \\
\hline & & Xylocpa (Neoxylocopa) suspecta Moure \& Camargo, 1988 & 19 & 0 & 19 \\
\hline Subtotal & & & 2259 & 114 & 2373 \\
\hline \multirow[t]{10}{*}{ APIDAE } & Outros Trigonini/Apis & Apis mellifera Linnaeus, 1758 & 607 & 0 & 607 \\
\hline & & Frieseomellita doederlini (Friese, 1900) & 3 & 0 & 3 \\
\hline & & Frieseomellita silvestri languida Moure, 1989 & 1 & 0 & 1 \\
\hline & & Trigonisca sp 1 & 1 & 0 & 1 \\
\hline & Bombini/Euglossini & Bombus morio (Swederus, 1787) & 1 & 0 & 1 \\
\hline & & Euglossa cordata (Linnaeus, 1758) & 31 & 0 & 31 \\
\hline & & Eulaema meriana flavescens Friese, 1899 & 1 & 0 & 1 \\
\hline & & Eulaema nigrita Lepeletier, 1841 & 11 & 0 & 11 \\
\hline & & Euplusia mussitans Fabricius, 1787 & 5 & 0 & 5 \\
\hline & Trigona & Trigona spinipes (Fabricius, 1793) & 660 & 0 & 660 \\
\hline Subtotal & & & 1321 & $\mathbf{0}$ & 1321 \\
\hline OTAL GERAL & & & 3770 & 213 & 3983 \\
\hline
\end{tabular}

Table II - Number of individuals per species of bee (Apoidea) collected in Abaeté, Salvador, Bahia State, from January to December 1996.

http://www.biotaneotropica.org.br 
Table III- Annual cycle of the species of Apoidea collected in Abaeté, Salvador, Bahia State, from January to December 1996.

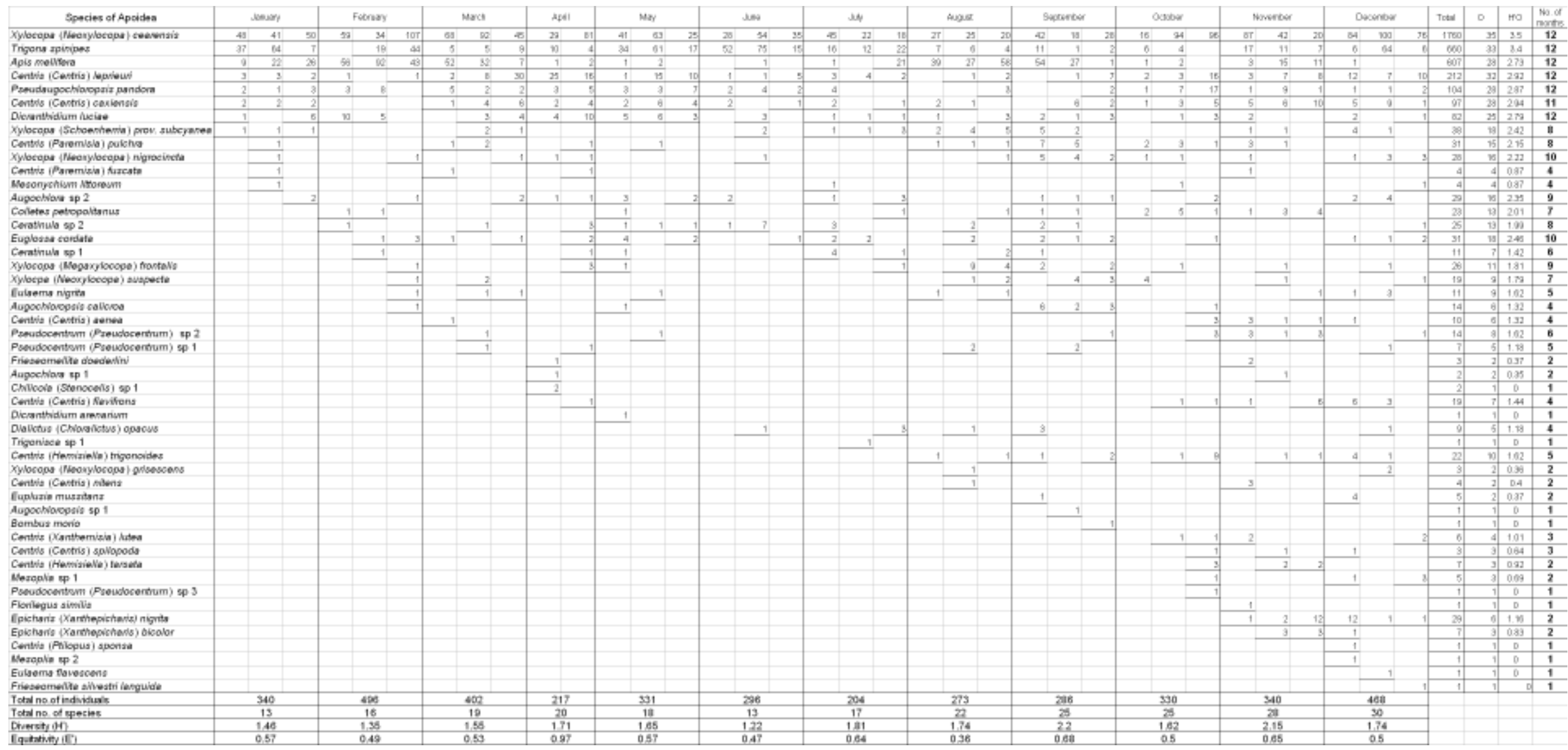

http://www.biotaneotropica.org.br 


\begin{tabular}{|c|c|c|}
\hline \multirow[b]{2}{*}{ Location } & \multicolumn{2}{|c|}{ Morisita's index } \\
\hline & Species & Genera \\
\hline $\begin{array}{c}\text { Maranhão }\left(2^{\circ} 29 ' S\right) \text { - Paraíba } \\
\left(7^{\circ} 3^{\prime} S\right)\end{array}$ & 0,36 & 0,54 \\
\hline $\begin{array}{c}\text { Paraíba (7º3'S) - Bahia } \\
\left.\text { (12º } 56^{\prime} S\right)\end{array}$ & 0,47 & 0,58 \\
\hline $\begin{array}{c}\text { Maranhão (2²9'S) - Bahia } \\
\left(12^{\circ} 56^{\prime} S\right)\end{array}$ & 0,31 & 0,86 \\
\hline
\end{tabular}

Table IV-Similarity in the fauna between three dune and restinga ecosystems in the Northeast of Brazil.

There was a significant variation in the month-to-month abundance of Apoidea ( $c^{2}=43.8$; g.l. $=11$; $\left.\mathrm{p}<0.001\right)$, indicating a tendency to seasonality. An seasonal distribution of bee individuals was not observed among 21\% (10) of the species collected; that were active for 10 to 12 months (Table III).

The majority of species were collected during a period between one and six months (Table III). This seasonal tendency of species abundance can be also observed in the species accumulation curve shown in Figure 2. Pearson correlation ( $\mathrm{r}=0.98)$ indicated a high relationship between the cumulative number of species and sampling effort in chronological sequence.

In general, the predominant species were active throughout the sampling period (Table III), except for Centris (Centris) caxiensis, which was not collected in February. There were variations in the monthly frequencies of these species, including the eusocial species Apis mellifera and Trigona spinipes, belonging to the family Apidae, that are not seasonal.

Figure 3 shows the relationship between abiotic factors, intensity of flowering (number of flowers in the visited plant species) and numbers of individuals of Apoidea collected in Abaeté during the year. The total number of specimens captured on each sampling day may be obtained by summing up the numbers for all species of the respective day in table 3

The minor variations observed in the temperature and relative humidity throughout the year were non-significant $\left(c^{2}=0.13\right.$, d.f. $=11, p<0.99$ and $c^{2}=-0.23$, d.f. $=11$ and $p$ $<0.99$, respectively).
Rainfall occurred throughout the year, but was more abundant between April (354.0 mm) and June (170.6 mm) and also in September (165.0 mm) and November (202.8 mm).

The availability of floral resources, as represented by the intensity of the flowering, seems to be the main regulating factor in the flight activity of bees in Abaeté. The foraging activity was directly related to the intensity of flowering in the field $(\mathrm{r}=0.68 ; \mathrm{p}<0.05)$.

Although flight activity of the bees in Abaeté was not correlated with rainfall ( $r=-0.47 ; \mathrm{p}>0.05)$, nor with wind speed $(r=-0.53, n=10 ; p>0.05)$, Figure 3 shows that there is a tendency towards an inverse relationship between these variables. The greatest number of specimens was collected during the drier months and with lower wind speeds.

Although in general, bees presented an ample and consistent activity throughout the day, they were most active between 08:00 to 14:00 hours, with a peak between 08:00 and 10:00 hours, decreasing gradually after that until the end of the afternoon (Figure 4). Although variations in the temperature and relative humidity through the day were not significant $\left(c^{2}=-0.38\right.$, g.l. $=11, \mathrm{p}<0.99$ and $c^{2}=1.21$, g.l. $=11$ and $\mathrm{p}<0.99$. respectively), the occurrence of small variations seemed to influence the flight activities of the bees, since they were more active during the hours in which the temperature was higher and thus the humidity lower.

\section{Discussion}

How is bee fauna of Abaeté structured, in relation to its composition and abundance? 
The distribution of the abundance of the species present in Abaeté fitted log-normality. This normal symmetrical bell-shaped curve is very common in ecological data set (Preston 1948). It is based in the assumptions that communities are composed of three classes of species: two extremes of rarity and dominance and high frequency with intermediate population size (MacArthur 1969).

A biological explanation for the canonical log normal distribution of species was proposed by Sugihara (1980). According to him there is a hierarchical multidimensional niche structure in the community which is reflected in the pattern of abundance. Sugihara's sequential breakage model as it is known provides an excellent working hypothesis for the diversification of niches in ecological communities (Magurran 1988).

Ecologists have been used the Sugihara's (1980) lognormal model of species diversity and abundance as a tool to assess the ecosystem integrity. Among them Kevan et al. (1997), in Canada, tested the effects of disruption of bee pollinators' guild of lowbush blueberry by application of insecticide to nearby forest. Their results showed on both spatial and temporal bases that fields unaffected by the pesticide fitted well to the log-normal model of species diversity and abundance, whereas affected fields departed from that pattern.

Our results show that the pattern of abundance of bees' species in Abaeté is consistent with the lognormal distribution. Thus, according to the above hypothesis the Abaeté sand dunes ecosystem is still conserved at least in relation to bees' community.

Comparing the Shannon-Wiener diversity indices (H') of Abaeté with similar ecosystems in Northeast of Brasil, Abaeté (2.04) is placed between those ecosystems in Maranhão (1.99) and Paraíba (2.30). The equitability indices of Pielou (J') varied from a minimum of 0.51 in Bahia, to a maximum of 0.64 in Paraíba. These values are very close to those found for caatinga environments (2.21, Viana 1999), which are considered to have a lower bee diversity. Several factors influence the local patterns of diversity in biotic communities (Rosenzweig 1999). In the coastal environments of the northeast region, the poor availability of resources combined to the high values of wind speed and light intensity must be limiting the number of species that compose the local bee associations.

As mentioned above, it has been observed as a general characteristic in these ecosystems (dunes and beaches) that there is a predominance of solitary bee species that have large bodies and are long lived. Anthophoridae was the family best represented in number of species, in all three sites, representing $53 \%$ of the total number of species in Bahia, 55\% in Paraíba and 58\% in Maranhão. In these sites, the majority of that family was composed of species of large bees, capable of enduring the environmental stress, principally caused by the strong winds.
On beaches and dunes a total absence or a low frequency of Meliponini species is observed, as is the case in Abaeté, and those species present show a low frequency of individuals. This fact can be attributed to the lack of appropriate places for nesting, as well as to the large areas without vegetation and to the strong winds; these characteristics act as limiting factors for this group of small bees. The Meliponini collected in Abaeté might be considered sporadic visitors, brought by the wind and/or lost and originating from the neighbouring forest environments. The presence of highly social species, such as Apis mellifera and Trigona spinipes, increased the Apidae abundance in the dunes. Apis mellifera can nidify within a wide range of places, and Trigona spinipes builds aerial nests. Nests of these two species were not found in the study area, leading to the conclusion that these species are attracted from outside to the dunes.

For the other species that compose the bee fauna of Abaeté, the nesting substrate does not appear to be a limiting factor. Several nests either inhabited and/or in construction of many of the species found in the study area were observed in the soil, as in the branches of Agaristha revoluta (Ericaceae). Thus we can say that most of the species collected are in fact residents of the dunes.

\section{Are there daily, seasonal or annual patterns in the flight activity of the bees in the Abaeté dunes?}

The annual cycle of bee diversity in Abaeté indicate a seasonal variation. The step-wise progression noted in the cumulative species curve, arranged chronologically, indicate that fauna change to some extent from season to season. For some bees' species the seasonal pattern was quite similar to those described in other studies accomplished in the Neotropical region (Heithaus 1979, Roubik 1989, Pedro \& Camargo 1991, Carvalho \& Bego 1996), in that the species are active year-round, with small variations in some periods. But most do show seasonality. According to Sakagami et al. (1967), the irregular appearance of certain species over long periods makes it difficult to recognize their seasonal pattern.

The peaks presented by Apis mellifera and Trigona spinipes, for instance, are probably due to the concentration of these eusocial species during attractive blooms, since these species are not particularly sensitive to variations in abiotic factors. The total absence or drastic reduction in the numbers of individuals of these bees could be associated to the presence of attractive floral resources outside the study area. Such a pattern related to the abundance of floral resources has also been described by other authors (Sakagami \& Laroca 1971, Pedro \& Camargo 1991).

Among the species of Centris, no particularly clear pattern of seasonality was observed, as those reported by Albuquerque (1998) in the dunes of Maranhão. Centris 
(Centris) caxiensis and Centris (Centris) leprieuri presented higher values of temporal diversity ( $\mathrm{H}^{\prime} \mathrm{O}$ ) than Pseudaugochloropsis pandora and Apis mellifera, species that present semisocial and eusocial behavior, respectively.

Individuals of Halictidae were active during the entire year. The distribution of individuals of this family into genera with differing levels of sociality, such as Augochloropsis and Dialictus; probably influences their pattern of abundance over the year.

More than $60 \%$ of the individuals of Colletes petropolitanus were captured during October and November, thereby presenting a tendency to seasonality in the Abaeté dunes.

The daily activity pattern of bees in Abaeté confirms the findings for these environments by Gottsberger et al. (1988) in São Luís, Maranhão. They observed that the frequency of flower visiting decreased considerably toward the end of the morning and in the afternoon.

Although flight activity was regulated through the course of the year, the availability of floral resources did not seem to be a determinant in the external activity of bees during the day in Abaeté, because the most dominant and visited species of plants remained in bloom during the whole day, secreting nectar (F O Silva and B F Viana unpublished data; C M Pigozzo and B F Viana unpublished data). This was unlike the daily occurrence in the dunes of Maranhão (Albuquerque 1998), where most of the flowers were not available to visitors in the afternoon.

Throughout the day, in Abaeté, wind speed reaching values above $4 \mathrm{~m} / \mathrm{s}$ seemed to have been an important limiting factor for flight activity among many species of small bees. Wind speed was also reported to exercise a strong influence on the flight activity of Apoidea in the Baturité region in Ceará State (Ducke 1910), in the rocky fields (“campo rupestre”) of Serra do Cipó, Minas Gerais State (Faria \& Camargo 1996) and in the dunes of São Luís do Maranhão (Albuquerque 1998).

Although wind interferes in the flight activity of insects, some solitary bees continue to fly in very strong winds (Linsley 1958). This fact was also observed in the Abaeté dunes: even though they were sometimes blown away from the flowers, species of Xylocopa and Centris continued to forage, flying low and close to the ground.

\section{Does the bee fauna of Abaeté have characteris- tics convergent to those of similar ecosystems?}

The Abaeté dunes house a bee fauna that includes species of wide geographical distribution, as well as eight morpho-species and a new species (recently described by Moure et al. 2003).
Considering the richness of the bee fauna, this region is poor when compared to results of studies from eastern Brazil, on local forest communities (Wilms et al. 1997) and in cerrado (Silveira \& Campos 1995) and coastal ecosystems in the southern part of Brazil (Zanella et al. 1998, Alves dos Santos 1999), where over hundred species were collected. On the other hand, Abaeté presents the same order of magnitude as that observed in similar ecosystems (beaches and dunes) (Albuquerque 1998, Silva \& Martins 1999), and in caatinga areas in the northeast of Brazil (Aguiar \& Martins 1997, Viana 1999).

When our data is compared with that of other studies on local dune communities (Maranhão, 2²9' S; 44²18'W; Albuquerque 1998), and restinga (Paraíba (7³'s; 3450’ W; Silva \& Martins 1999), in which similar standardized methodologies were employed and where the number of species is also small, the degree of similarity between the three locations was found to be less than 0.5 (Table IV). Since these are faunas of physically similar environments, higher values were expected. It is probable that the local composition of the bee fauna is not only influenced by neighboring habitats and local variation of abiotic factors, but could also be related to the composition of the flora, which varies considerably between these areas.

When comparing the fauna at genus level (Table IV), the similarity between the areas increases considerably, and a convergence between the habitat types under analysis is observed. In comparison with the dunes of Maranhão and the dunes of Bahia, the values rise to 0.86. In Abaeté, the morpho-functional groups identified coincide with the taxonomic categories of genus and family. These morpho-functional categories form food guilds that include species characterized by many similarities, including body size, social structures, foraging strategy and taxonomy.

The functional group concept (Gitay \& Noble 1995) allied to that of ecological equivalents has been much utilized in studies regarding ecological communities, operation of ecosystems and identification of priorities for conservation (Lawton \& Brown 1994, Tilman \& Downing 1994, Walker 1995).

In an analysis of the bee fauna of the dunes and restinga of the Brazilian Northeast from the morpho-functional perspective, the convergence between the faunas of these environments becomes evident. The bees inhabiting these areas present very similar demands for resources and nesting sites. In these areas, solitary bees predominate; with large bodies and capable of foraging under adverse abiotic conditions (strong winds and high light intensity). It is noteworthing the presence of ecological equivalents, such as for instance, Xylocopa (Neoxylocopa) cearensis, in Bahia and Xylocopa (Neoxylocopa) carbonaria Smith, 1854, in Maranhão, both predominant species in their locations and with similar niches. 
Some general tendencies observed in the environments of dunes and restinga sandbanks in the northeastern region lead to the conclusion that in these environments there is a structural pattern of functional types, abundance, dominance and diversity with a notable similarity between them. However, for a more extensive analysis, on a regional level, as well as for confirmation of the tendencies observed in this study, and the establishment of general patterns, it will be necessary to carry out a greater number of samplings, with standardized methodology, at varying latitudes along the coast of northeast Brazil.

\section{Acknowledgements}

The authors wish to thank Professor Pe. Jesus Santiago Moure and Professor Danuncia Urban, from Federal University of Paraná, for the identification of bees' species; to the National Institute of Meteorology (INMET), for providing climatic data; to the members of Bee Biology and Ecology Laboratory of Federal University of Bahia for their assistance with the field sampling; and to the comments of three anonymous referees greatly improved the final version of the manuscript. BFV thanks PICDT/CAPES/UFBA for the fellowship during the period of research. This research was supported by FAPESB through a grant to BFV.

\section{References}

AGUIAR, C.M.L. \& MARTINS, C.F. 1997. Abundância relativa, diversidade e fenologia de abelhas (Hymenoptera, Apoidea) na caatinga, São João do Cariri, Paraíba, Brasil. Iheringia Sér. Zool. 83:151-163.

ALBUQUERQUE, P. 1998. Abelhas silvestres (Hymenoptera, Apoidea) e suas fontes de alimento em um ecossistema de dunas, na ilha do Maranhão, Maranhão, Brasil: composição, fenologia e interações. Tese de doutorado, Universidade de São Paulo, Ribeirão Preto.

ALVES DOS SANTOS, I. 1999. Abelhas e plantas melíferas da mata atlântica, restinga e dunas do litoral norte do Estado do Rio Grande do Sul. Rev. Bras. entomol. 43:191-223.

ARAÚJO, D.S.D. \& LACERDA, L.D. 1987. A natureza das restingas. Ciênc. hoje 6:42-48.

CAMARGO, J.M.F. \& MAZUCATO, M. 1984. Inventário de apifauna e flora apícola de Ribeirao Preto, SP, Brazil. Dusenia 14:55-87.

CARVALHO, A.M.C. \& BEGO, L.R. 1996. Studies on Apoidea fauna of cerrado vegetation at the Panga Ecological Reserve, Uberlândia, MG, Brazil. Rev. Bras. entomol. 40:147-156.

DUCKE, A. 1902. Beobachtungen über Blütenbesuch, Erscheinungszeit etc der bei Pará vorkommenden Bienen. Allg. Z. Ent. 17:321-325.

DUCKE, A. 1906. Neue Beobachtungen über die Bienen der Amazonasländer. Allg. Z. Ent. 2:51-60.
DUCKE, A. 1908. Contributions à la connaissance des hyménoptères des amériques. Rev. entomol. 27(3):28-87.

DUCKE, A. 1910. Explorações botânicas e entomólogicas no estado do Ceará. Rev. trimens. Inst. Ceará 24:3-61.

EITEN, G. 1968. Vegetation forms. Bol. Inst. Bot. 4:1:88.

FARIA, G.M. \& CAMARGO, J.M.F. 1996. A flora melitófila e a fauna de Apoidea de um ecossistema de campos rupestres, Serra do Cipó, MG, Brasil. In Anais $2^{\circ}$ Encontro sobre Abelhas (C.A. Garófalo, coord.), Ribeirão Preto, v.2, p.217-228.

GOTTSBERGER, G, CAMARGO, J.M.F. \& SILBERBAUERGOTTSBERGER, I. 1988. Abee pollinated tropical community: The beach dune vegetation of Ilha de São Luís, Maranhão, Brazil. Bot. Jahrb. Syst. 109:469-500.

HEITHAUS, E.R. 1979. Community structure of neotropical flower visiting bees and wasps: diversity and phenology. Ecology 60:190-202.

KEVAN, P., GRECO, C.F. \& BELAOUSSOFF, S. 1997. Lognormality of biodiversity and abundance in diagnosis and measuring of ecosystemic health: pesticide stress on pollinators on blueberry heaths. J. appl. ecol. 34:11221136.

KREBS, C. J. 1998. Ecological methodology. 2 ed. Pearson Benjamin Cummings; San Francisco.

LAROCA, S., CURE, J.R. \& BORTOLI, C. 1982. A associação das abelhas silvestres (Hymenoptera, Apoidea) de uma área restrita no interior da cidade de Curitiba (Brasil): uma abordagem biocenótica. Dusenia 13: 93-117.

LAROCA, S. 1995. Ecologia: princípios e métodos. Editora Vozes, Petropólis.

LAWTON, J.H. \& BROWN, V.K. 1994. Redundancy in ecosystems. In Biodiversity and Ecosystem Function (E.D. Schulze \& H.A. Mooney, eds.). Springer-Verlag, Berlin, p.255-270.

LINSLEY, E.G. 1958. The ecology of solitary bees. Hilgardia 27:543-597.

LUDWIG J.A. \& REYNOLDS, J.F. 1988. Statistical ecology: A primer on methods and computing. John Wiley \& Sons Inc., New York.

MACARTHUR, R.H. 1969. Patterns of communities in the tropics. Biol. J. Linn. Soc. 1:19-30.

MARTINS, C.F. 1994. Comunidade de abelhas (Hym., Apoidea) da caatinga e do cerrado com elementos de campos rupestres do estado da Bahia, Brasil. Rev. nordest. biol. 9:225-257.

MICHENER, C.D. 1965. A classification of the bees of the Australian and South Pacific regions. Bull. Am. Mus. Nat. Hist. 130: 1-362, + 1-15.

MICHENER, C.D. 2000. The bees of the world. Johns Hopkins Univ Press, Baltimore, Maryland. 
MORAWETZ, W. 1983. Dispersal and succession in an extreme tropical habitat: coastal sands and xeric woodland in Bahia (Brazil). Sonderbd. naturwiss. 7:359-380.

MOURE, J.S., OLIVEIRA, F.F \& VIANA, B.F 2003. Descrição de uma espécie nova de Centris (Hymenoptera, Apoidea) das dunas litorâneas da Área de Proteção Ambiental das Lagoas e Dunas de Abaeté, Salvador, Bahia, Brasil (1256’'S; 38²1’W). Rev. Bras. entomol. 47(4):569-572.

PEDRO, S.L.M. \& CAMARGO, J.M.F. 1991. Interactions on floral resources between the Africanized honey bee community (Hymenoptera: Apoidea) in natural "cerrado" ecosystem in southeast Brazil. Apidologie 22: 397-415.

PINHEIRO-MACHADO, C., ALVES DOS SANTOS, I., SILVEIRA, F.A., KLEINERT, A.M.P. \& IMPERATRIZFONSECA, V.L. 2002. Brazilian bee surveys: state of knowledge, conservation and sustainable use. In Pollinating bees: the conservation link between agriculture and nature (P.G. Kevan \& V.L. Imperatriz-Fonseca, eds.). Ministério do Meio Ambiente, Brasília, p.115-129.

RIBAS, L.A., HAY, J.D. \& CALDAS-SOARES, J.F. 1994. Moitas de restinga: Ilhas ecológicas? p.79-88. In III Simpósio de ecossistemas da costa brasileira: subsídios a um gerenciamento ambiental- Restingas e praias (S. Watanabe, coord.). ACIESP, Serra Negra, v.3, p.79-88.

ROSENZWEIG, M.L. 1999. Species diversity in space and time. Cambridge University Press, Cambridge.

ROUBIK, D.W. 1989. Ecology and natural history of tropical bees. Cambridge Univ. Press, New York.

SAKAGAMI, S.F., LAROCA, S. \& MOURE, J.S. 1967. Wild bee biocenotics in São José dos Pinhais (Pr), south Brazil. Preliminary report. J. Fac. Sci. Hokkaido Univ. Ser. 6 19:190-250.

SILVA, M.C.M. \& MARTINS, C.F. 1999. Flora apícola e relações tróficas de abelhas (Hymenoptera: Apoidea) em uma área de restinga (Praia de Intermares, Cabedelo-PB, Brasil). Principia 7:40-51.

SILVEIRA, F.A.\& CAMPOS, M.J.O. 1995. A melissofauna de Corumbataí (SP) e Paraopeba (MG) e uma análise da biogeografia das abelhas do cerrado brasileiro (Hymenoptera, Apoidea). Rev. Bras. entomol. 39:371-401.

SOUTHWOOD, R. \& HENDERSON, P.A. 2000. Ecological methods. 3 ed. Blackwell Science Inc., Oxford.

TILMAN, D. \& DOWNING, J.A. 1994. Biodiversity and stability in grasslands. Nature 367: 363-365.

VIANA, B.F. 1999. A comunidade de abelhas (Hymenoptera, Apoidea) das dunas interiores do rio São Francisco, Bahia, Brasil. Neotrop. Entomol. 28:635-645.
WILMS, W., WENDEL, L., ZILLIKENS, A., BLOCHTEIN, B. \& ENGELS, W. 1997. Bees and other insects recorded on flowering trees in a subtropical Araucaria forest in southern Brazil. Stud. neotrop. fauna environ. 32(4):220-226.

WALKER, B.H. 1995. Conserving biological diversity through ecosystem resilience. Conserv. biol. 9:747-752.

ZANELLA, C.V., SCHWARTZ FILHO, D.L. \& LAROCA, S. 1998. Tropical bee island biogeography: diversity and abundance patterns. Biogeographica 74: 103-115.

Title: A community of flower-visiting bees (Hymenoptera: Apoidea) in the coastal sand dunes of Northeastern Brazil

Authors: Blandina Felipe Viana \& Astrid de Matos Peixoto Kleinert

Biota Neotropica, Vol. 5 ( number 2): 2005

http://www.biotaneotropica.org.br/v5n2/pt/ abstract?article+BN00305022005

Date Received 08/15/2004 - Revised 05/22/2005

Accepted 07/01/2005

ISSN 1676-0611 